\title{
MOLECULAR WEIGHT DISTRIBUTION OF POLLUTANTS IN LEACHATE FROM FULL SCALE LANDFILL SITE
}

\author{
YAMAN F.B. ${ }^{1, *}$ \\ ÇAKMAKCI M. ${ }^{1}$ \\ CAMPAGNA M. ${ }^{1,2}$ \\ ÖZKAYA B. ${ }^{1}$
}

Received: $30 / 12 / 2015$

Accepted: 04/05/2016

Available online: 13/05/2016

\author{
${ }^{1}$ Yildiz Technical University \\ Department of Environmental Engineering \\ Istanbul, Turkey \\ ${ }^{2}$ University of Catania
Catania, Italy \\ Department of Civil and Environmental Engineering \\ ${ }^{2}$ University of Catania
Catania, Italy
}

*to whom all correspondence should be addressed: e-mail: fbyaman@yildiz.edu.tr

\section{ABSTRACT}

The main objective of this study was to investigate the differences between the main pollutants in young and intermediate age landfill leachate in terms of molecular weight distribution (MWD). Parameters of chemical oxygen demand (COD), five day - biochemical oxygen demand $\left(\mathrm{BOD}_{5}\right)$, ultraviolet-visible spectrophotometry (UV-VIS spectrum), total kjehldahl nitrogen (TKN), ammonia nitrogen ( $\left.\mathrm{NH}_{4}-\mathrm{N}\right)$ and colour were fractioned by membranes with the nominal pore size of $1 \mu \mathrm{m}, 0.05 \mu \mathrm{m}, 100 \mathrm{kDa}, 50 \mathrm{kDa}, 10$ $\mathrm{kDa}, 1 \mathrm{kDa}$ and $0.5 \mathrm{kDa}$. According to the MWD results appropriate treatment technology could be choosen easily. According to the MWD results the ratio of soluble fractions ( $<0.5 \mathrm{kDa})$ to total COD was $34 \%$ in young leachate (YL), whereas low molecular weight (MW) fractions were dominant in intermediate leachate (IL) having this ratio of $71 \%$. Presence of lower MW compounds in IL was also confirmed with UV-VIS absorbance spectra and its spectrum was higher than the YL. According to the specific ultraviolet absorption (SUVA) values, the organic contents of all of these processes were hydrophilic. TKN and $\mathrm{NH}_{4}$ $\mathrm{N}$ analysis showed that in IL all the nitrogen present is in ammoniacal form, instead in $\mathrm{YL}$ there is still the presence of organic nitrogen. Furthermore more than half of the TKN was less than $0.5 \mathrm{kDa}$ while $6 \%$ and $16 \%$ TKN found in wastewater from IL and YL was higher than $1 \mu \mathrm{m}$ respectively. The observations of this study may provide useful criteria to choose a suitable landfill leachate treatment processes.

Keywords: Leachate age, landfill, molecular weight.

\section{INTRODUCTION}

Landfill is one of the major disposal methods in the solid waste management system and landfilling remains nowadays the most widely used municipal solid waste (MSW) treatment in most countries (Berthe et al., 2008; Campagna et al., 2013; Yaman et al., 2015). Landfills release a wide range of chemical compounds due to the waste degradation in the entire life cycle. The release of indeterminated volumes of leachate would introduce the risks to public health and the surrounding environment (Liu et al., 2015; Christensen et al. 2001).

Nowadays, although landfill engineering practice and regulations have been applied in protecting the surrounding environment by the use of leachate treatment systems and the controlling of leachate removal (Zhang et al., 2007; Oloibiri et al., 2015; Nivala et al., 2007; Renou et al., 2008). Treatment efficiency has not been satisfied yet. Moreover, in some developing countries, there is a considerable 
number of closed landfill areas which were operated without any engineering protection, and leachate from these sites is may be arise over the next several decades.

High concentration of organic matter and inorganic components, heavy metals, xenobiotic organic compounds and microorganisms can be found in the landfill leachate. (Zhang et al., 2007). Thus, a detailed characterization of landfill leachate is very important to choose appropriate treatment technologies and to evaluate its effects on the environment. Determination of MWD of pollutants in leachate also helps to evaluate appropriate treatment technologies and performance of the leachate treatment systems by providing information on the physical characteristic of pollutants in the leachate. However, MWD may affect the behavior and reactivity of pollutants and this information may be very important to comment the fate of the pollutants (Dulekgurgen et al., 2006).

Numerous studies indicated that leachate properties varied significantly as the landfill becomes older (Renou et al., 2008; Buck and Bruland 2007; Campagna et al., 2013; Shehzad et al., 2015). As a landfill moves through each phases of its life cycle, the leachate compositions change dramatically, which might introduce additional challenges for the development of environmental protection technologies. For example, the concentration of organic matter in $\mathrm{YL}$ is generally higher than the concentration in IL (ISTAC 2003; Campagna et al. 2013; Amor et al., 2015) The organic matter in water bodies is of great importance due to its effect on fate and transport of contaminants, speciation of metals (Magda et al., 2015; Regadío et al., 2015; Christensen et al., 2011) and the overall ecology and dynamics of water bodies (Regadío et al., 2015; Christensen et al., 2011). Before taking any decision about the treatment plant processes, the concentration of organic matter and other pollutants should be determined. COD is one of the most used conventional parameters to evaluate the organic matter concentration. The characterization of the MWD of COD is a valuable tool when assessing the effect of this material on the performance of water treatment systems as well as its geochemical origin. For example, the size as defined by the MWD has been identified to influence both microbial populations (ISTAC 2003; Buck and Bruland 2007; Amor et al., 2015; Magda et al., 2015; Regadío et al., 2015) and the removal of COD in water treatment systems. However, it is known that components of the COD vary widely due to the complexity of landfill leachates (Steinberg, 2004; Buck and Bruland 2007; Zhang et al., 2012; Amor et al., 2015) Therefore, it is necessary to investigate the pollutant composition in landfill leachate, which can improve the understanding about the distribution, environmental behaviors and fates of individual components. As a general rule, leachate is characterized by high values of $\mathrm{COD}, \mathrm{pH}, \mathrm{NH}_{4}-\mathrm{N}$ and heavy metals, as well as strong colour and bad odour.

Landill leachate has a wide range of $\mathrm{NH}_{4}-\mathrm{N}$ concentration (Kulikowska, 2012). The treatment of $\mathrm{NH}_{4}-\mathrm{N}$ concentration in the leachate is very vital step because $\mathrm{NH}_{4}-\mathrm{N}$ causes to toxicity. As a result determining of $\mathrm{MWD}$ of $\mathrm{NH}_{4}-\mathrm{N}$ helps to evaluate proper treatment processes. For example, biological methods are only effective to treat low molecular weight (LMW) compounds, for high molecular weight (HMW) NH $\mathrm{N}_{4} \mathrm{~N}$ can be treated by combination of physical-chemical and biological methods (Zhang et al., 2013).

UV-Vis and colour are other important parameters for the leachate treatment. UV-Vis absorption is known to be a useful indicator for aromaticity and MW of organic matter in the water (Williams, 1998). For example, HMW substances can be easily treated than low molecular substances with coagulation (Yaman et al., 2015).

Landfill leachate is a very dark coloured liquid formed matters and the decomposition of organic matter such as humic acid may cause the water to be yellow, brown or black (Wiley et al., 2014). Landfill leachate could be a major contamination source of ground and surface water. Therefore, it is important to find sustainable option to treat this colour effectively before being discharged into the environment (Wiley et al., 2014).

This study is focused on determination of MWD of YL and IL from a full-scale landfill in order to recognize their characteristics and differences, which could help evaluate appropriate treatment technologies and performance of the leachate treatment systems. 


\section{MATERIALS AND METHODS}

\subsection{Site and leachate samples}

Istanbul is the biggest metropolitan city of Turkey with a population over 15 million and it has to manage 10,000 tons of solid waste every day. Municipal solid waste (MSW) compositions are averagely $42.97 \%$ organics, $7.76 \%$ paper, $4.8 \%$ plastic, $9.37 \%$ nylon, $6.2 \%$ glass, $5.8 \%$ metal, and $9.28 \%$ others (ISTAC, 2003).The samples of landfill leachate used in this study were all collected from a full-scale Odayeri landfill site in Istanbul, and stored in plastic holders at $4{ }^{\circ} \mathrm{C}$. The samples belong to leachate of 1-2 years old (YL), and nearly 10 years old (IL). All leachate samples were collected from drainage pipe-line of the landfill site. The characterizations of YL and IL are shown in Table 1.

Table 1 Characterization of YL and IL

\begin{tabular}{ccc}
\hline \multirow{2}{*}{ Parameters } & \multicolumn{2}{c}{ Leachate types } \\
\cline { 2 - 3 } & YL & IL \\
\hline Colour, PtCo & 8100 & 3100 \\
\hline $\mathrm{pH}$ & 6,5 & 7,7 \\
\hline $\mathrm{COD}, \mathrm{mg} \mathrm{l}^{-1}$ & 31700 & 3850 \\
\hline $\mathrm{BOD}_{5}, \mathrm{mg} \mathrm{l}^{-1}$ & 28700 & 1700 \\
\hline $\mathrm{BOD}_{5} / \mathrm{COD}$ & 0,91 & 0,44 \\
\hline $\mathrm{DOC}_{\mathrm{mg}} \mathrm{m}^{-1}$ & 11180 & 1440 \\
\hline $\mathrm{UV}_{254}$ & 42,7 & 27,8 \\
\hline $\mathrm{UV}_{280}$ & 32,7 & 21 \\
\hline $\mathrm{UV}_{320}$ & 21,7 & 10,7 \\
\hline $\mathrm{TKN}_{32} \mathrm{mg} \mathrm{l}^{-1}$ & 2640 & 3550 \\
\hline $\mathrm{NH}_{4}-\mathrm{N}, \mathrm{mg} \mathrm{l}^{-1}$ & 2325 & 3530 \\
\hline Conductivity, $\mathrm{mS} \mathrm{cm}^{-1}$ & 32,6 & 37,8 \\
\hline $\mathrm{TDS}, \mathrm{g} \mathrm{I}^{-1}$ & 21,8 & 32,6 \\
\hline
\end{tabular}

\subsection{Membrane characteristics}

In this study, microfiltration membranes of $1 \mu \mathrm{m}$ and $0.05 \mu \mathrm{m}$ pore sizes and ultrafiltration membranes (from Microdyn Nadir Co.) with a nominal molecular weight (NMWL) of $100 \mathrm{kDa}, 50 \mathrm{kDa}, 10 \mathrm{kDa}, 1 \mathrm{kDa}$ (from Pall Co.) and $0.5 \mathrm{kDa}$ (from Spectrum laboratories, Inc.) were used for the sequential filtration process. Moreover $100 \mathrm{kDa}, 50 \mathrm{kDa}, 10 \mathrm{kDa}, 1 \mathrm{kDa}$ and $0.5 \mathrm{kDa}$ filters nominal pore sizes are; $7.9 \mathrm{~nm}, 6.3$ $\mathrm{nm}, 3.5 \mathrm{~nm}$, and $2 \mathrm{~nm}$ respectively. At the present, there is a difficult task to reach to a consensus one single definition of size fractions. This difficulty was pointed out in a study (Williams, 1998) in which the variations among the exact cut off sizes given in the studies using categorization based on particle size segregation are highlighted. It was considered the Millipore's definition of NMWL: a UF membrane with stated NMWL will retain at least $90 \%$ of a globular solute of that molecular weight in Daltons (Millipore Ultrafiltration Guide, 2007). UF membranes have a distribution of pore diameters, not just pores of one diameter (Leiviska et al., 2008).

\subsection{Sequential filtration}

Microfiltrations were performed using a lab-scale filtration system with flat sheet membranes. Ultrafiltrations were performed with a stirred cell (Amicon, Model 8400), it consists of a methylmethacrylate glass holder with a Volume of $350 \mathrm{~mL}$. After all filtration, almost $100 \%$ volume of water was filtered successfully. Effective membrane filter diameter and filtration area were $76 \mathrm{~mm}$ and $41.8 \mathrm{~cm}^{2}$, respectively. The samples were filtered by a pressure applied with nitrogen gas, the operation pressure was 2 bar, except for the last $0.5 \mathrm{kDa}$ filtration, where a pressure of 4 bar was used because $0.5 \mathrm{kDa}$ filter pore size was very small and 2 bar was not strong enough for filtration. The filters were first washed with $70 \%(7+3)$ ethanol for 20 min., thereafter washed in deionized water to remove the ethanol in apparatus and membrane. The sequential filtration was carried out with the following steps shown in the Figure 1. 
In the first step $800 \mathrm{~mL}$ of sample filter $1 \mu \mathrm{m}$ after $100 \mathrm{ml}$ sample was taken and $700 \mathrm{~mL}$ of water filter with $0.05 \mu \mathrm{m}$, and these steps were continued sequentially.

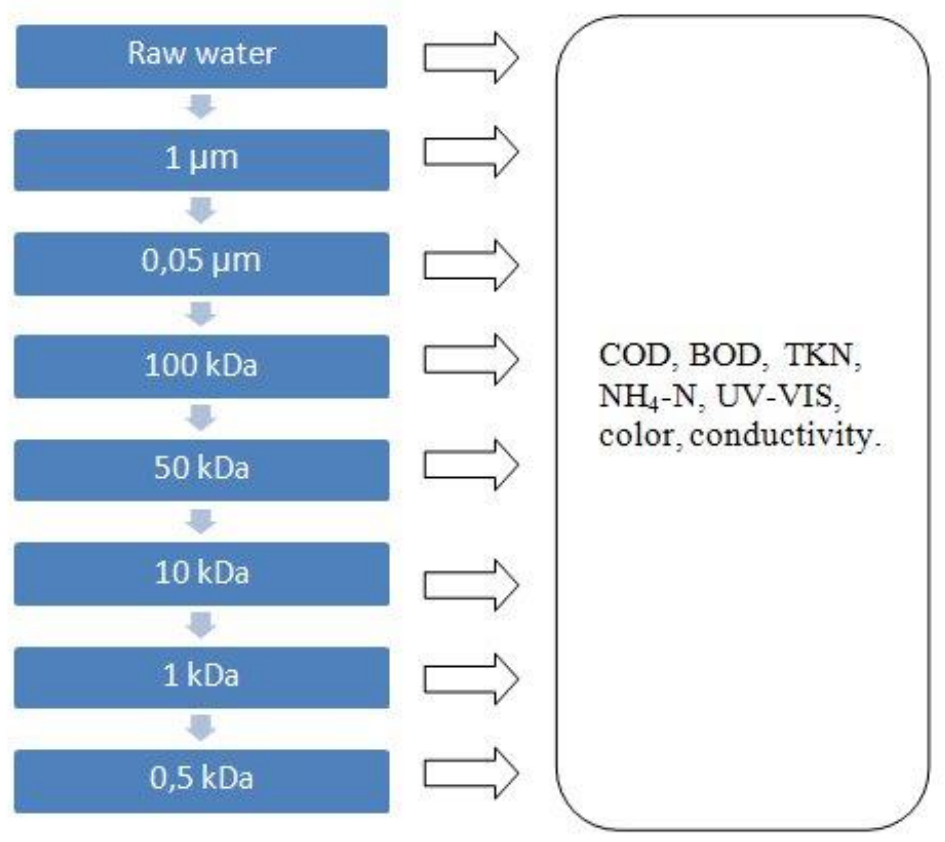

Figure 1 Sequential filtration of MWD and the key parameters measured

\subsection{Analytical}

All the analyses were carried out following the Standards Methods for Water and Wastewater of American Public Health Association (APHA), American Water Work Association (AWWA) and Water Environment Federation (WEF). The COD analysis was executed by open reflux method with the method number of 5220-B in standard method of APHA-AWWA-WEF. For UV-VIS spectrum, the absorptions at 254, 280, 285 and $320 \mathrm{~nm}$ wavelengths were investigated.

The 5-day $\mathrm{BOD}_{5}$ test was carried out following the Standard Procedure of 5210-B in standard methods of APHA-AWWA-WEF. TKN and NH4-N were analysed according to the SM $4500 \mathrm{~N}_{\text {org }} \mathrm{C}$ and SM $4500 \mathrm{NH}_{3} \mathrm{C}$, respectively. Organic nitrogen was calculated by the differences of TKN and $\mathrm{NH}_{4}-\mathrm{N}$. The conductivity analyses were carried out using a multi-parameter of Thermo Scientific (model Orion 5 star).

\section{RESULTS AND DISCUSSION}

The first characterization indicates that $\mathrm{BOD}_{5}$ and $\mathrm{COD}$ values are higher in the $\mathrm{YL}$, because the degradation and humification process is still at the beginning in $\mathrm{YL}$. $\mathrm{BOD}_{5} / \mathrm{COD}$ ratio is a common way to evaluate the biodegradability of the leachate (Sophonsiri et al., 1999; Amor et al., 2015). It can be noticed that, the IL is less biodegradable than the young one, moreover, the $\mathrm{BOD}_{5} / \mathrm{COD}$ ratio in IL is still nearly 0.4 , which indicates relatively low biodegrability (Leiviska et al., 2008). This also means that the leachate is not properly "old" because it is still biodegradable, so this sample is not a real old and stabilized leachate, but rather an "intermediate" leachate (Leiviska et al., 2008).

Normally, old landfill leachates (> 10 years), present a low $\mathrm{BOD}_{5} / \mathrm{COD}$ ratio $(<0.1)$, indicating low biodegradability due to the release of HMW recalcitrant organic molecules (Jensen et al.,1999; Vilar et al., 2011; Amor et al.,2015). The YL has a high $\mathrm{BOD}_{5} / \mathrm{COD}$ ratio, therefore a biological process is strongly recommended, because there is high amount of organic substrate available for bio-degradation. The higher UV absorbance in YL is probably due to the fact that in this sample the NOM (like humic and fulvic acid) has a higher concentration than in the IL (Kang et al.,2002). 


\subsection{Organic contents}

It can be seen from Figure 2, the particulate COD fractions $(>0.05 \mu \mathrm{m})$ of $\mathrm{YL}$ and IL were $16 \%$ and $14 \%$, respectively. These ratios indicated that the COD of both leachates were mainly comprised of dissolved organics. COD fractions for $100 \mathrm{kDa}-50 \mathrm{kDa}, 50 \mathrm{kDa}-10 \mathrm{kDa}, 10 \mathrm{kDa}-1 \mathrm{kDa}, 1 \mathrm{kDa}-0.5 \mathrm{kDa}$ and $<0.5 \mathrm{kDa}$ were $14 \%, 1 \%, 4 \%, 31 \%$ and $32 \%$ in $Y L$ and $9 \%, 4 \%, 1 \%, 2 \%$ and $70 \%$ in IL, respectively. More than half of the COD in YL and IL had medium molecular weight (MMW) $(<0.05 \mu \mathrm{m}$ and $>0.5 \mathrm{kDa})$. According to these results, a biological process is strictly recommended for the treatment of $\mathrm{YL}$ and IL because the microorganisms can use these medium and LMW substrates, for the reasons that part of it is the readily biodegradable COD taken into account the $\mathrm{BOD}_{5}$ concentration of the $\mathrm{YL}$ (Table 2). Zhao et al., (2012), also reported that LMW of COD can be easily used by microorganisms. In accordance with microbial degradation kinetics, the soluble readily biodegradable COD fraction consists of nearly small biodegradable particles, which are easily passesd across cell membrane and then metabolized in a short time (Zhao et al., 2012). On the contrary, using of the particular biodegradable COD and the soluble slowly biodegradable COD fractions takes longer since these component comprise larger particle and need extra cellular breakdown prior to their transport into the cell for biodegradation. COD fractionation is quite important due to the response of biomass in activated sludge varies with particle size of these components.As a result of these, the huge range of biodegradation rates defined for different COD fractions is likely to have a correlation with physical categorization in terms of particle size and physical state in solution (Dulekgurgen et al., 2006).

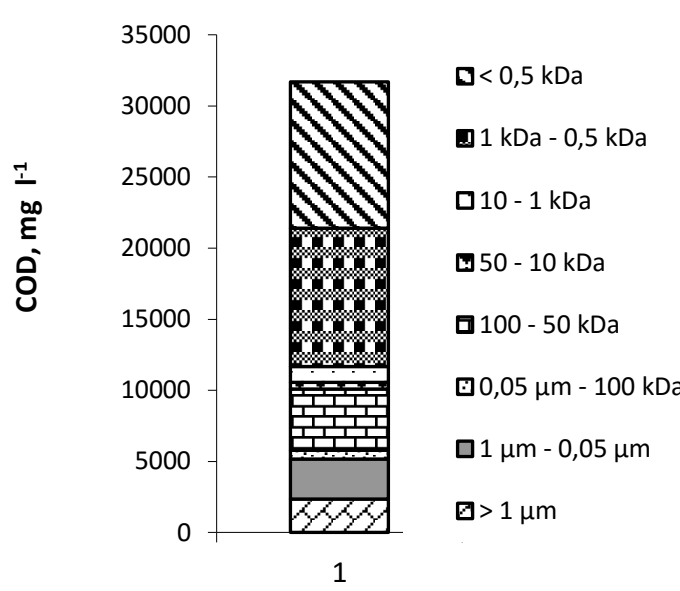

YL

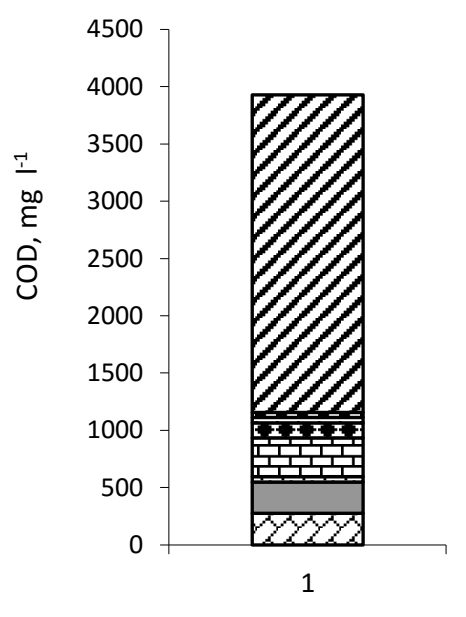

IL

Figure 2. MWD of COD concentration

Therefore, a traditional biological process, or, better, an MBR process can be very effective for COD removal for YL (Zhao et al., 2012). With leachate aging, there is a shift of COD fractions towards HMW. The IL, nevertheless, seems to have a higher COD fraction of LMW $(<0.5 \mathrm{kDa})$. The results indicate that significant parts of COD in IL have very LMW. This can be due to the fact that the COD of IL is in soluble inert form (Bijan and Mohensi 2005). For this kind of IL an advanced pre-oxidation $\left(\mathrm{O}_{3}\right.$, fenton process, etc.) may be necessary to break down the inert compounds and make them ready for biodegradation. Besides, the low $(<0.5 \mathrm{kDa})$ and high molecular $(>0.05 \mu \mathrm{m})$ weight distributions were $71 \%(2773 \mathrm{mg}$ COD/L) and 14\%, respectively, in IL and Kang et al.(Kang et al., 2002) also observed similar results.

On the one hand, RO and NF membranes which have lower molecular weight cut off (MWCO) than 0.5 kDa can not seen feasible due to LMW of COD in YL and IL (Cakmakci et al., 2012; Ozyaka et al., 2015)

However, flocculation and precipitation processes can be effective HMW than $0.1 \mathrm{kDa}$ (Uner et al.,2006). As seen in Table 2, $\mathrm{BOD}_{5}$ concentration in $\mathrm{YL}$ is very high and most of its $\mathrm{LMW}$ of COD can be utilized by 
microorganisms. Thus, biological treatment should be applied to treat $\mathrm{YL}$ before membrane processes ( $\mathrm{Li}$ et al., 2009).

After biological treatment of organic matter, membrane processes can be used to enhance treated water quality.

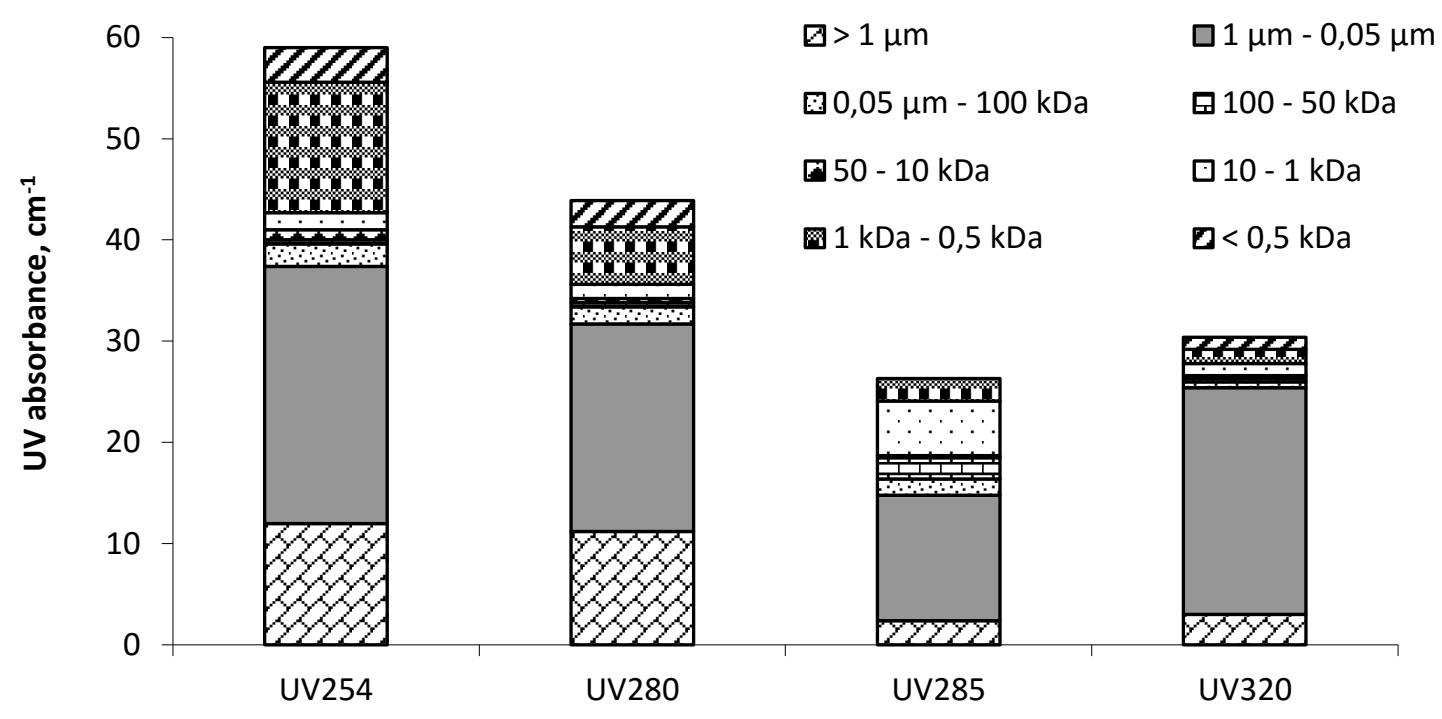

$\mathrm{YL}$

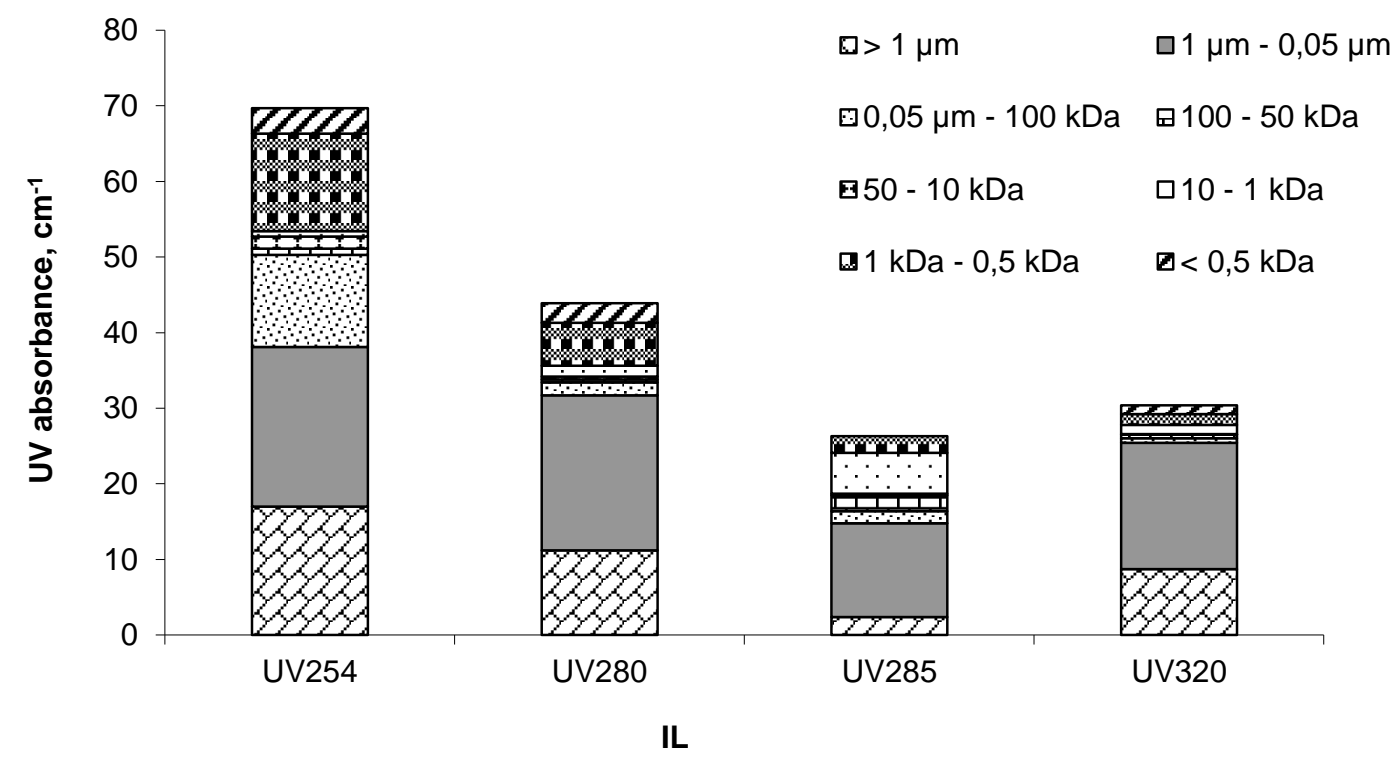

Figure 3. MWD of UV-Vis absorbance

\subsection{UV-VIS spectra}

The total spectra is used to understand the MWD of the samples. The UV-VIS spectra of samples containing high concentrations of organic matters (humic acids, fulvic acids) are the result of overlapping absorbances of numerous different chromophores caused by the very complicated structures of humic substances (Edzwald and Tobiason, 1999). 
UV-Vis absorbances at different wavelengths $(254,280$ and 320) were studied to determine the organic matter contents in each MWD. It is known that high UV-Vis absorbance between $190 \mathrm{~nm}$ and $800 \mathrm{~nm}$ shows the existing of humic substances, whereas aromatic content of organic matter can be observed at low UV-Vis wavelengths (Chen and Tobiason, 1999). Aromatic organics are best detected using the 254 $\mathrm{nm}$ wavelength, because of the strong absorption properties of these double bond organics. In addition, saturated ketones and some aromatic organics detected at $280 \mathrm{~nm}$ wavelength and $285 \mathrm{~nm}$ wavelengths is an indicator of DOC, and $320 \mathrm{~nm}$ is also an indicator of COD in the landfill leachate (Gu et al., 2002).

In this study, the results of the UV-Vis absorptions were shown in Figure 3. The absorbance value at 254 $\mathrm{nm}$ was almost same for both $\mathrm{YL}$ and IL. The absorbance values at $254 \mathrm{~nm}$ was high for both leachates and it means that aromatic organics may be dominants organics in the leachates. A strong decline of UV-Vis absorbance was observed after $0.5 \mathrm{kDa}$ filtration for both $\mathrm{YL}$ and IL.

As expected at $280 \mathrm{~nm}$, theabsorbance values was higher with IL, because of the presence of high molecular weight and high aromaticity organic matter. $285 \mathrm{~nm}$ is an indicator of DOC, and it can be noticed that the absorbance values is higher in the IL than in the $\mathrm{YL}$.

Most part of UV-Vis absorbances were removed by $100 \mathrm{kDa}$. Thus, aromatic contents of organic matter can be removed by ultrafiltration membranes which have $100 \mathrm{kDa}$ or lower MWCO.

\subsection{SUVA}

If SUVA value is higher than 4, it indicates HMW organic matter which has hydrophobic character and if SUVA is lower than 2 , it indicates LMW organic matter which has hydrophilic character (Bijan and Mohensi 2005, Li et al., 2009; Zhao et al., 2012; Cakmakci et al., 2012; Ozyaka et al., 2015). Figure 4 shows the distribution in SUVA values of YL and IL. SUVA values was lower than $2 \mathrm{l} / \mathrm{mg} . \mathrm{m}$ which indicate that these waters are in hydrophobic characteristics. Hence conventional coagulation-flocculation is not a proper method for removing highly hydrophilic organic (Edzwald and Tobiason et al., 1999.).

SUVA with MW of $0.1 \mu \mathrm{m}$ was $38 \%$ and $40 \%$ in YL and IL, respectively. According to these values, it can be concluded that SUVA is mostly composed of high molecular organics in both leachates. It was obvious that pretreatment with or over $0.1 \mu \mathrm{m}$ can successfully remove major part of SUVA.

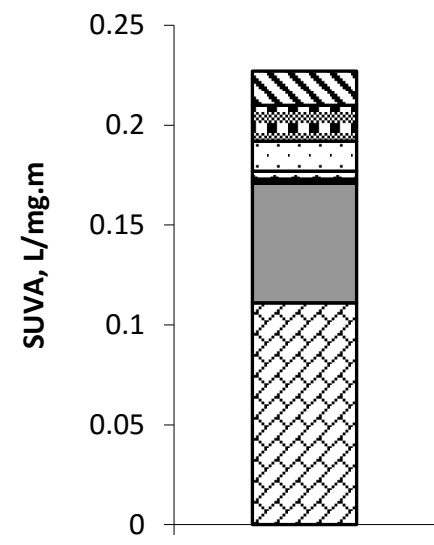

YL

$$
\begin{aligned}
& \mathbf{D}<0,5 \mathrm{kDa} \\
& \text { d } 1 \mathrm{kDa}-0,5 \mathrm{kDa} \\
& \square 10-1 \text { kDa } \\
& \text { 口50 - } 10 \text { kDa } \\
& \text { 巴100 - } 50 \text { kDa } \\
& \text {. } 0,05 \mu \mathrm{m}-100 \mathrm{kDa} \\
& \square 1 \mu \mathrm{m}-0,05 \mu \mathrm{m} \\
& \square>1 \mu \mathrm{m}
\end{aligned}
$$

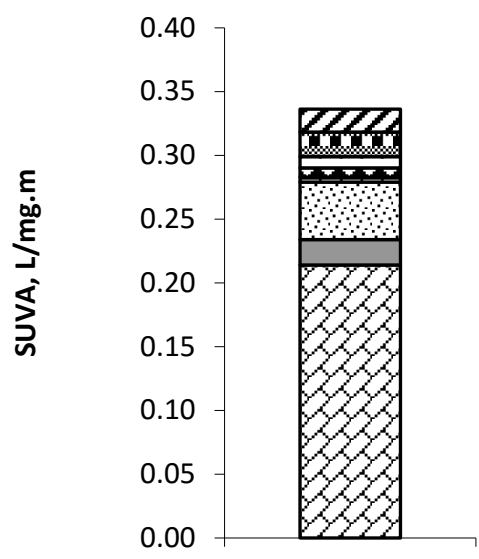

IL

Figure 4 MWD of SUVA 254 values

\subsection{Nitrogen}

Concentrations of TKN and $\mathrm{NH}_{4}-\mathrm{N}$ are shown in Figure 5. As seen from Figure 5, there is a bit diffences between TKN and $\mathrm{NH}_{4}-\mathrm{N}$ concentrations. It means a part of organic nitrogen is still available in $\mathrm{YL}$. Unlike 
$\mathrm{YL}$, organic nitrogen is almost converted into $\mathrm{NH}_{4}-\mathrm{N}$ due to the nearly same concentrations of TKN and $\mathrm{NH}_{4}-\mathrm{N}$. These results are in accordance with Kang et al., (2002), and Renou et al., (2008), studies.

The main source of $\mathrm{NH}_{4}-\mathrm{N}$ in leachate results from the anaerobic hydrolysis of proteins in the solid wastes. $\mathrm{NH}_{4}-\mathrm{N}$ slowly releases from the solids because of the slow anaerobic hydrolysis. Thus, $\mathrm{NH}_{4}-\mathrm{N}$ concentration increases day by day in landfill leachate. If TKN is almost equal to $\mathrm{NH}_{4}-\mathrm{N}$, it can be assumed that the landfill is stabilized (Hautala et al., 2000).

Most of TKN and $\mathrm{NH}_{4}-\mathrm{N}$ (66.40\% and 66.70 respectively) passed from $1 \mathrm{kDa}$ (Figure 5) from the both leachates was very low. These values show that when precipitation is added to flocculation, MF, UF and NF membranes are not sufficient to remove TKN. Zaho et al. (2012) found that LMWorganic nitrogen was effectively removed by means of biological processes. In the study, $\mathrm{TKN}$ and $\mathrm{NH}_{4}-\mathrm{N}$ were mostly less than $1 \mathrm{kDa}$ MWD; this means the TKN and $\mathrm{NH}_{4}-\mathrm{N}$ can also be reduced by biological treatment processes such as combination of anoxic and aerobic.

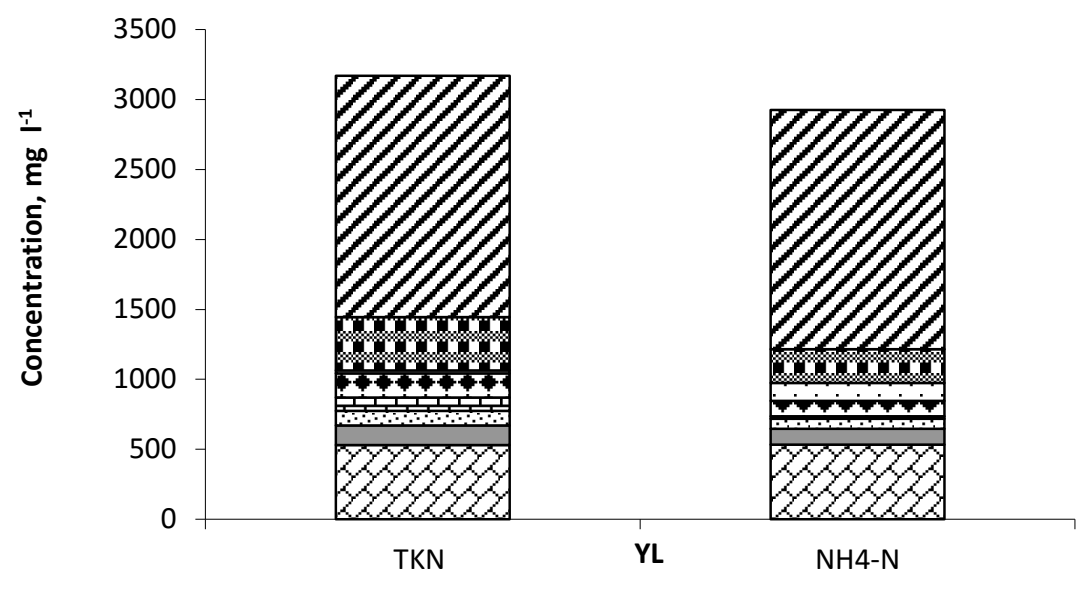

$$
\begin{aligned}
& \square<0,5 \mathrm{kDa} \\
& \text { 象 } 1 \mathrm{kDa}-0,5 \mathrm{kDa} \\
& \square 10-1 \mathrm{kDa} \\
& \square 50-10 \mathrm{kDa} \\
& \square 100-50 \mathrm{kDa} \\
& \square 0,05 \mu \mathrm{m}-100 \mathrm{kDa} \\
& \square 1 \mu \mathrm{m}-0,05 \mu \mathrm{m} \\
& \square>1 \mu \mathrm{m}
\end{aligned}
$$

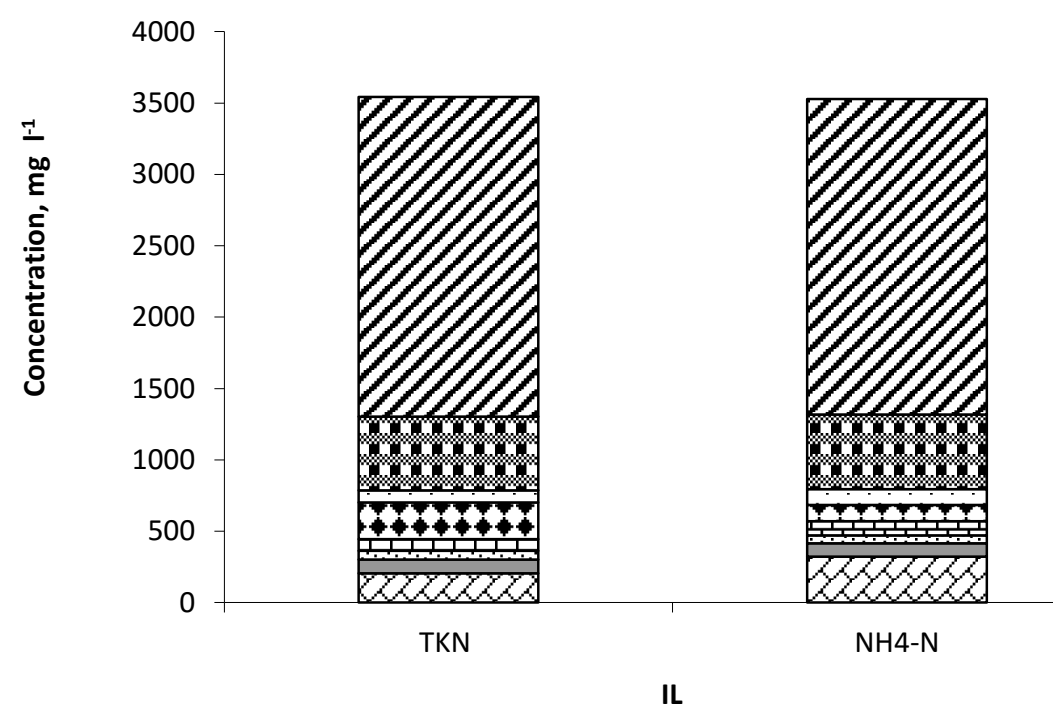

$\boldsymbol{\Xi}<0,5 \mathrm{kDa}$

$\mathbf{0} 1 \mathrm{kDa}-0,5 \mathrm{kDa}$

$\square 10-1 \mathrm{kDa}$

$\square 50$ - $10 \mathrm{kDa}$

田 $100-50 \mathrm{kDa}$

$\square 0,05 \mu \mathrm{m}-100 \mathrm{kDa}$

$\square 1 \mu \mathrm{m}-0,05 \mu \mathrm{m}$

ㅇ $>1 \mu \mathrm{m}$

Figure $5 \mathrm{MWD}$ of TKN and $\mathrm{NH}_{4}{ }^{+}-\mathrm{N}$

\subsection{Colour}

Colour is an important water parameter due to the astehtic and the live life in water. The leachate colour dependences on the landfill ages as shown in Figure 6. All samples in YL and IL are of brownish colour, due to the aromatic structures of humic and fulvic acids (ISTAC, 2003). 
The colour of the $\mathrm{YL}$ is darker than the IL. Most of colour of both leachates can be removed by $1 \mu \mathrm{m}$ and $0.05 \mu \mathrm{m}$ according to the MWD. This means that the largest part of colour is produced by colloidal suspended solids and HMW of dissolved matters. In YL, removal efficiencies of colour by $1 \mu \mathrm{m}$ and 0.05 $\mu \mathrm{m}$ is higher than IL. These results are nearly similar with Leiviska et al., (2008), studies. They obtained the highest turbidity and colour removal in correspondence of the $0.22 \mu \mathrm{m}$. Moreover, after $10 \mathrm{kDa}$ MWD, the colour of the $\mathrm{YL}$ and IL can be reduced up to $93 \%$ and $67 \%$, respectively. Thus, it is assumed that most parts of colour in YL and IL can be removed by microfiltration or ultrafiltration membrannes. When an NF with an MWCO of $1 \mathrm{kDa}$ is applied, the colour can be decreased by $96 \%$ and $78 \%$ from the YL and IL. In addition to membrane filtration, ozonation and biological treatment can also be applied in order to remove colour. After ozonation, biological treatment or carbon adsorption should be applied in order to remove LMW organics before being filtered through the NF or RO membranes (Campagna et al., 2013). Moreover, low-molecular-weight organics with high biodegradability are easily biodegraded by anaerobic treatment (Leiviska et al., 2008).
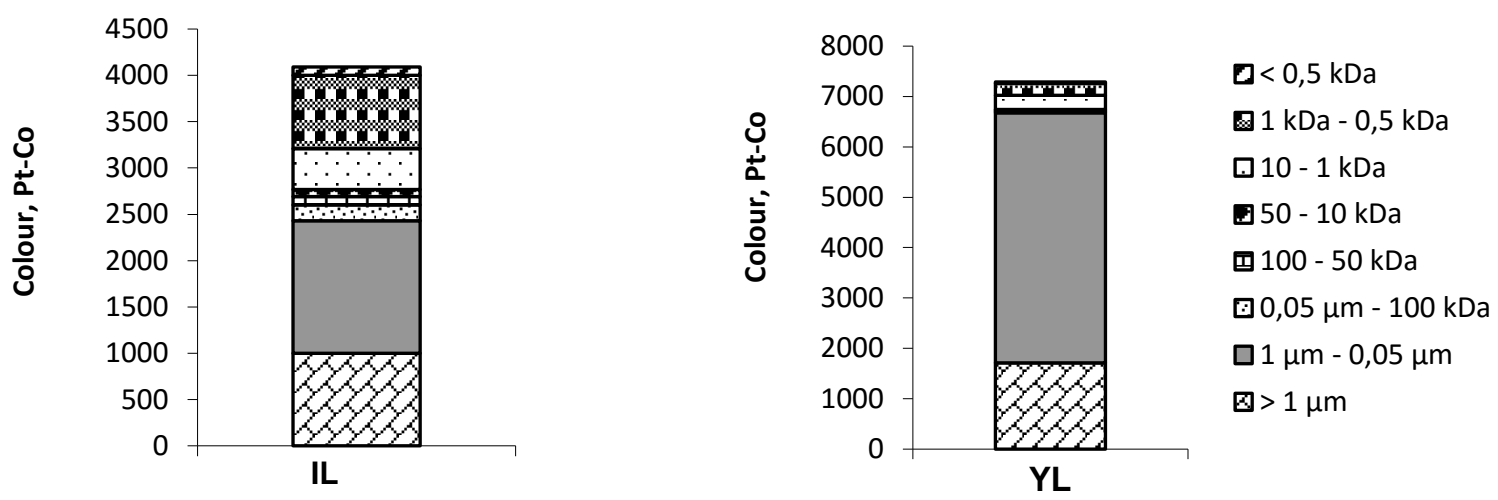

Figure 6. MWD of colour

\section{CONCLUSIONS}

In this study, YL and IL were analyzed and evaluated according to the pollution concentration and MWD. The following conclusions can be drawn:

- $\quad \mathrm{COD}$ in YL is constituted from LMW compounds, which can easily be used by microorganisms. Traditional biological process, or, better, an MBR process can be very effective for removal of LMW COD. Unlike YL, IL is constituted from soluble and non-biodegradable compounds, so the biological treatment may not be very effective to remove COD. Some solutions to treat this kind of leachate could be mixing it with $\mathrm{YL}$, or an advanced oxidation to break down the nonbiodegradable compounds and make them ready to biodegradation.

- $100 \mathrm{kDa}$ or lower MWCO ultrafiltration membranes can be removed most part of UV-Vis absorbances.

- SUVA values show that YL and IL organic matters have hydrophilic characters. Thus, biological and physical (membrane processes) prosesses can be used to remove organic matter in YL and IL.

- Most part of nitrogen is $\mathrm{NH}_{4}{ }^{+}-\mathrm{N}$ in $\mathrm{YL}$ while almost all of it is $\mathrm{NH}_{4}{ }^{+}-\mathrm{N}$ in IL. In both cases the membrane treatment system was not effective for nitrogen removal according to the MWD analyses. Bological treatment processes such as combination of anoxic and aerobic can be used to treat TKN and NH4-N. 
- Most part of colour may occurred due to colloidal suspended solids and HMW matters according to the MWD analyses. The colour can be removed by $100 \mathrm{kDa}$ and lower MWCO of ultrafiltration membranes.

- This study only shows the evaluations of YL and IL detailed characterizations. Thus, treatability studies may be applied to understand the effects of MWD on treatment performance.

\section{References}

Amor C., Torres-Socías E., Peres J., Maldonado M.I., Oller I., Malato S. and Luca M. (2015), Mature landfill leachate treatment by coagulation/flocculation combined with Fenton and solar photo-Fenton processes, Journal of Hazardous Materials, 286, 261-268.

Berthe C., Redon E. and Feuillade G.J. (2008), Fractionation of the organic matter contained in leachate resulting from two modes of landfilling: An indicator of waste degradation, Journal of Hazardous Materials, 154, 162-171.

Bijan L. and Mohseni M. (2005), Integrated ozone and biotreatment of pulp mill effluent and changes in biodegradability and molecular weight distribution of organic compounds, Water Research, 39, 3763-3772.

Buck K.N. and Bruland K.W. (2007), The physicochemical speciation of dissolved iron in the Bering Sea, Alaska.Limnol. Oceanogr, 52, 1800-1808.

Cakmakci M. and Ozyaka V.Ş. (2012), Aerobic composting leachate treatment by the combination of membrane processes, Waste Management and Research, 31, 187- 193.

Campagna M., Cakmakci M., Yaman F.B. and Ozkaya B. (2013), Molecular weight distribution of a full-scale landfill leachate treatment by membrane bioreactor and nanofiltration membrane, Waste Management, 33, 866-870.

Chen J., Edzwald J.K. and Tobiason J.E. (1999), Enhanced coagulation: Us requirements and a broader view, Water Science and Technology, 40, 63-70.

Christensen T.H., Kjeldsen P., Bjerg P.L., Jensen D.L., Christensen J.B., Baun A., Albrechtsen H.J. and Heron C. (2001), Biogeochemistry of landfill leachate plumes, Applied Geochemistry, 16, 659-718.

Dulekgurgen E., Dogruel S., Karahan O. and Orhon D. (2006), Size distribution of wastewater COD fractions as an index for biodegrability, Water Research, 40, 273-282.

Edzwald J.K. and Tobiason J.E. (1999), Enhanced coagulation: USA requirements in abroader view, Water Science and Technology, 40, 9-12.

Grøn C., Christensen J.B., Jensen D.L., Kjeldsen P. and Østfeldt P. (2000), Organic halogens in landfill leachates, Water, Air and Soil Pollution, 120, 331-345.

Gu H., Boeuf E.J., Pan H.J. and Dai S. (2002), Spectroscopic characterization of the structural and functional properties of natural organic matter fractions, Chemosphere, 48, 59-68.

Hautala K., Peuravuori J. and Pihlaja K. (2000), Measurement of aquatic humus content by spectroscopic analyses, Water Research, 34, 246-258.

ISTAC, Istanbul Metropolitan Municipality Environmental Protection and Waste Material Recycling Corporation booklet, 2003, istanbul Turkey.

Jensen D.L. and Christensen T.H. (1999), Colloidal and dissolved metals in leachates from four Danish landfills, Water Research, 33(9), 2139-2147.

Kang K.H., Shin H.S. and Park H. (2002), Characterization of humic substances present in landfill leachates with different landfill ages and its implications, Water Research, 36, 4023-4032.

Kulikowska D. (2012), Nitrogen removal from landfill leachate via the nitrite route, Brazilian Journal of Chemical Engineering, 29, 211-219.

Leiviska T., Nurmesniemi H., Poykio R., Ramo J., Kuokkanen T. and Pellinen J. (2008), Effect of biological wastewater treatment on the molecular weight distribution of soluble organic compounds and on the reduction of BOD, COD and $P$ in pulp and paper mill effluent, Water Research, 42, 3952-3960.

Li R., Yue D., Liu J. and Nie Y. (2009), Size fractionation of organic matter and heavy metals in raw and treated leachate, Waste Management, 29, 2527-2533. 
Liu Z., Wub W., Shi P. and Guo J.S. (2015), Characterization of dissolved organic matter in landfill leachate during the combined treatment process of air stripping, Waste Management, 41, 111-118.

Magda M., Abd El-Salam A. and Gaber I. (2015), Impact of landfill leachate on the groundwater quality: A case study in Egypt, Journal of Advanced Research, 6, 579-586.

Nivala J., Hoos M.B., Cross C., Wallace S. and Parkin G. (2007), Treatment of landfill leachate using an aerated, horizontal subsurface-flow constructed wetland, Science of the Total Environment, 380, 19-27.

Oloibiri V., Ufomba B., Chys M., Audenaert T.M., Demeestere K. and Van Hulle W.H. (2015), A comparative study on the efficiency of ozonation and coagulation-flocculation as pretreatment to activated carbon adsorption of biologically stabilized landfill leachate, Waste Management, 43, 335-342.

Ozyaka V.Ş., Çakmakci M., Yaman F.B., Özkaya B. and Karadağ D. (2015), Treatment of compost leachate by membrane processes, Environmental Engineering and Management Journal, 14(9), 2237-2241.

Regadío M., Ruiz A.I., Rodríguez-Rastrero M. and Cuevas J. (2015), Containment and attenuating layers: An affordable strategy that preserves soil and water from landfill pollution, Waste Management, 46, 408-419.

Renou S., Givaudan J.G., Poulain S., Dirassouyan F. and Moulin S. (2008), Landfill leachate treatment: Review and opportunity, Journal of Hazardous Materials, 150, 468-493.

Shehzad A., Bashir M.J.K., Sethupathi S. and Lim J. (2015), An overview of heavily polluted landfill leachate treatment using food waste as an alternative and renewable source of activated carbon, Process Safety and Environmental Protection, 9, 309-318.

Sophonsiri C. and Morgenroth E. (2004), Chemical composition associated with different particle size fractions in municipal, industrial and agricultural wastewaters, Chemosphere, 55, 691-703.

Steinberg C., Regulatory impacts of humic substances in lakes,in: P.E. O'Sullivan, C.S. Reynolds (Eds.), The Lakes Handbook, Limnology and Limnetic Ecology, Blackwell Publishing.,2004, 1: 153-196.

Uner H., Dogruel S., Arslan-Alaton I., Babuna F.G. and Orhon D. (2006), Evaluation of coagulation-flocculation on a COD-based molecular size distribution for a textile finishing mill effluent, J. Environ. Sci. Health. Part A, 41, 1899-1908.

Vilar V.J.P., Rocha E.M.R., Mota F.S., Fonseca A., Saraiva I. and Boaventura RAR (2011), Treatment of a sanitary landfill leachate using combined solar photo-Fenton and biological immobilized biomass reactor at a pilot scale Water Research, 45, 2647-2658.

Wiley J., Ghosh P., Indu S. and Thakur S. (2014), Enhanced removal of COD and colour from landfill leachate in a sequential Bioreactor, Bioresource Technology, 170, 10 -19.

Williams P., Waste Treatment and Disposal, 1998, John Wiley and Sons, UK.

Yaman F.B., Cakmakci M., Karadağ D., Özkaya B., Bali V. and Dora B. (2015), Molecular weight distributions in cottondyeing textile wastewaters, Desalination and Water Treatment, DOI: 10.1080/19443994.2015.1049956.

Yan H., Ian T., Zhang C. and Zhou Q. (2015), Perfluoroalkyl acids in municipal landfill leachates from China: Occurrence, fate during leachate treatment and potential impact on groundwater, Science of the Total Environment, 524-525, 23-31.

Zhang G., Qin L., Meng Q., Fan Z. and Wub D (2007), Investigation on characteristics of leachate and concentrated leachate in three landfill leachate treatment plants, Bioresource Technology, 142, 261-268.

Zhang H., Wu X. and Li X. (2012), Investigation on characteristics of leachate and concentrated leachate in three landfill leachate treatment plants, Chemical Engineering Journal, 210, 188-194.

Zhang Q., Tian B.H., Zhang X., Ghulam A. and Fang C.R. (2013), Investigation on characteristics of leachate and concentrated leachate in three landfill leachate treatment plants, Waste Management, 33, 2277-2286.

Zhao R., Novak J.T. and Goldsmith C.D. (2012), Evaluation of on-site biological treatment for landfill leachates and its impact: a size distribution study, Water Research, 46, 3837-3848. 